\title{
A FAMÍLIA E O PERÍODO GESTACIONAL: Um estudo a partir da composição do genograma e ecomapa, em mulheres usuárias de drogas
}

\author{
Maria Luíza Soares Veloso ${ }^{1}$
}

Gilmar Antoniassi Junior ${ }^{2}$

\section{RESUMO}

INTRODUÇÃO: No período gestacional, uma boa qualidade no relacionamento do casal e interfamiliar configuram um ambiente emocionalmente favorável para uma gestação tranquila, predizendo assim a chegada de uma criança com melhor perspectiva de desenvolvimento. Isto se mostra como um momento que requer total atenção para com a mãe e o bebê, pois, no momento do nascimento de um filho há uma reatualização e reedição dos aspectos constitutivos da própria mãe com a dinâmica familiar em que ela está inserida. Neste prospecto, é necessário ater-se para aquelas gestantes que se encontram no grupo de risco devido o abuso do álcool e outras drogas, onde a repercussão é maior pelo comprometimento irreversível da saúde mãe e o feto. Este trabalho se justifica por entender-se que as emoções têm papel relevante na vida familiar e acreditar-se que estas podem afetar a gestante e posteriormente o desenvolvimento de seu filho. OBJETIVO: O objetivo deste estudo é de verificar no período gestacional o tipo de família em que a gestante está inserida frente as características da: Dinâmica global familiar - Relação Conjugal - Relação Parental, em mulheres usuárias de álcool e outras drogas atendidas na Rede de Saúde do SUS, em uma cidade da região do Alto Paranaíba, estado de Minas Gerais, Brasil. METODOLOGIA: Pesquisa de campo qualitativa transversal exploratória por meio de estudo de casos selecionados através de levantamento aleatório envolvendo mulheres no período gestacional

\footnotetext{
${ }^{1}$ Acadêmica do curso de Psicologia da Faculdade Patos de Minas - FPM. Email de contato: mlsveloso@hotmail.com.

${ }^{2}$ Mestre em Promoção da Saúde da Universidade de Franca - UNIFRAN - e docente do Departamento de Graduação em Psicologia da Faculdade Cidade Patos de Minas - FPM.
} 
de risco. Como instrumento de coleta de dados utilizou-se do Genograma Familiar, Ecomapa e o inventário de percepção familiar: Os dados foram coletados por meio de atendimentos individualizados agendados com as gestantes, onde foi assinado o TCLE. Para análise, os dados foram transcritos e categorizadas conforme - contexto social; indicadores de saúde envolvimento com álcool e outras drogas; contexto gestacional e a relação familiar. Averiguando - Tipo de Família; Sentimentos; Apoio elou Suporte de Enfretamento; Representação Gestacional; Significado Gestacional; Afetividade; e Esperança. A classificação da tipologia familiar ocorreu por meio de modelos referente à Estrutura $e$ Dinâmica Global; Relação Conjugal; e Relação Parental, tomada como base o Roteiro de Tipologia Familiar e suas variáveis. Já o inventário de percepção de suporte familiar foi analisado conforme a padronização do instrumento. RESULTADOS: CASO 1: Margarida (fictício) - 23 anos, reside sozinha e o pai da atual gestação está na prisão. Seu genograma indica três relacionamentos passageiros. Um filho de cada relacionamento. Os filhos são cuidados pelo ex na casa de avó. Em relação à atual gestação, Margarida afirma não ter sido planejada, reconhecendo desespero quando ficou sabendo [...] "queria morrer" e estava em uso frequente das drogas juntamente com seu parceiro e pai da criança. CASO 2: Luana (fictício) - 38 anos e usuária desde os 16 anos de idade. Reside com a mãe de 82 anos. Seu genograma indica que esteve em três relacionamentos e os filhos residem o mais velho de 11 anos com o pai e o de 5 anos com o tio. Sobre o uso das drogas diz que acha uma porcaria e está parada, usando apenas cigarro. Fez uso de crack até saber da gravidez aos dois meses. Demonstra saber dos riscos para o bebê decorrente dos danos do uso frequente das drogas e do cigarro no período gestacional. DISCUSSÃO: É possível observar que ambas vivem em ambientes familiar e social precários. São mulheres de classe baixa, com pouca escolaridade sem uma profissão especifica. A adversidade em torno ao envolvimento paterno é um dilema envolto aos casos, uma vez que, diversos estudos apontam para os aspectos emocionais na constituição do sujeito. Por meio da relação simbólica, os filhos cuidados de outrem, garantem sua estabilidade emocional. O uso de drogas lícitas e ilícitas durante a gestação sempre foi uma questão de difícil abordagem. A expansão do consumo de drogas psicoativas atingiu as mulheres em idade fértil aumentando o consumo nessa população específica consideravelmente. Isso gerou diferentes desafios em várias esferas, no que tange ao campo da saúde, família e sociedade em geral. CONSIDERAÇÕES: A pesquisa e referencial teórico, correlacionados a uma ampla parcela da sociedade que vive em condições de dinâmicas familiares semelhantes e/ou diferentes, apontam para a necessidade de atenção aos diferentes conflitos que cercam as famílias com padrões disfuncionais. Foi possível por meio deste estudo e instrumentos utilizados, cumprir o objetivo proposto, constatando que as dinâmicas familiares, seus conflitos inter-relacionais afetam diretamente as gestantes e 
consequentemente seu entorno e a futura pessoa. Assim, este estudo pode servir de possibilidade para diversos programas que abranjam a prevenção do uso de drogas, visto que este potencializa os conflitos familiares, trazendo sequelas para as próximas gerações.

Palavra-chave: família; genograma; gestação. 